\title{
Use of intra-aortic balloon pump in patients with acute coronary syndrome and cardiogenic shock at the University Hospital Centre Osijek, in the period from 2014 to 2015
}

\section{Zorin Makarović*, Sandra Makarović, Damir Kirner, Robert Steiner, Ivica Bošnjak, Marin Vučković, Dragan Novosel, Dražen Mlinarević}

University of Osijek School of Medicine, University Hospital Centre Osijek, Osijek, Croatia
RECEIVED:

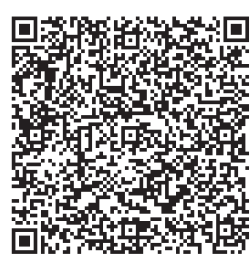

KEYWORDS: intra-aortic balon pump, shock, acute coromary syndrome CITATION: Cardiol Croat. 2016;11(3-4):101. | DOI: http://dx.doi.org/10.15836/ccar2016.101

*ADDRESS FOR CORRESPONDENCE: Zorin Makarović, Klinički bolnički centar Osijek, J. Huttlera 4, HR-31000 Osijek, Croatia. / Phone: +385-91-591-6875 / E-mail: zorinmakarovic2@net.hr

ORCID: Zorin Makarović, http://orcid.org/0000-0002-6689-3177 • Sandra Makarović, http://orcid.org/0000-0002-7487-1189 Damir Kirner, http://orcid.org/0000-0002-6001-3378 • Robert Steiner, http://orcid.org/0000-0003-2250-9855 Ivica Bošnjak, http://orcid.org/0000-0002-0223-4287 • Marin Vučković, http://orcid.org/0000-0003-1010-181x Dragan Novosel, http://orcid.org/0000-0001-5609-7073 • Dražen Mlinarević, http://orcid.org/0000-0003-3246-4056

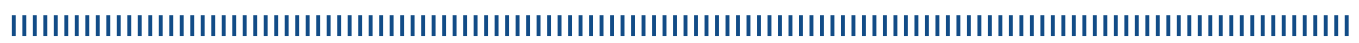

There are conflicting evidence regarding the use of intra-aortic balon pump (IABP) in acute coronary syndrome and shock patients. ${ }^{1,2}$ Current European Society of Cardiology (ESC) Guidelines does not recommend IABP to be routinely used. It is intended to be used in patients with non ST-segment elevation myocardial infarction (NSTEMI) with acute mechanical complications. ESC Guidelines considered meta-analyses by Sjauw el al and the major randomized clinical trial IABP SHOCK II. This research did not confirm degraded mortality 30 days after ST-segment elevation myocardial infarction (STEMI) with shock. There are several flaws to this study: the absence of long-term survival, not taking into account patients with mechanical complications of myocardial infarction, NSTEMI patients and cardiogenic shock after 12 hours. $50 \%$ of patients had blood pressure $\geq 90 \mathrm{mmHg}$, which rise the question of inclusion criteria. However, meta-analyses showed significant reduction in mortality in cardiogenic shock after STEMI in patients treated with thrombolysis and IABP, but without primary percutaneous coronary intervention. New randomized clinical trials are needed, so that a definite conclusion on long-term survival could be made, as well to establish if there are groups within those patients, which could benefit from the use of IABP.

We present our IABP experience, in University Hospital Centre Osijek, in time period from 2014 to 2015 in acute coronary syndrome patients and cardiogenic shock, and their short term outcome and survival. This is ongoing study planned to follow long term outcome as well.

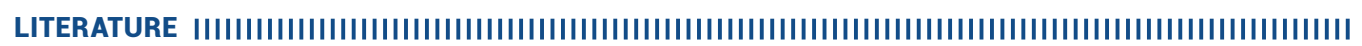

1. Thiele H, Zeymer U, Neumann FJ, Ferenc M, Olbrich HG, Hausleiter J, et al; IABP-SHOCK II Trial Investigators. Intraaortic balloon support for myocardial infarction with cardiogenic shock. N Engl J Med. 2012;367(14):1287-96. DOI: http://dx.doi.org/10.1056/NEJMoa1208410

2. Sjauw KD, Engström AE, Vis MM, van der Schaaf RJ, Baan J Jr, Koch KT, et al. A systematic review and meta-analysis of intra-aortic balloon pump therapy in ST-elevation myocardial infarction: should we change the guidelines? Eur Heart J. 2009;30(4):459-68. DOI: http://dx.doi.org/10.1093/eurheartj/ehn602 